\title{
Kultursammenstød \\ - kunsten at rykke et vulkanudbrud 100 år
}

\section{Af Carsten R. Kjaer, Aktuel Naturvidenskab}

Dateringen af de store vulkanudbrud i bronzealderen på den græske ø Santorini diskuteres stadig flittigt i fagkredse.

For et års tid siden kunne GeologiskNyt berette om fundet af en olivengren på den græske ø Santorini, der kunne dateres meget præcist til år 1613 f.Kr. \pm 13 år. Det interessante var, at de geologiske vidnesbyrd pegede på, at grenen stammede fra et oliventræ, der var blevet begravet i pimpsten fra det voldsomme vulkanudbrud, der gjorde en ende på den minoiske kultur på øen - og som er et af historiens største vulkanudbrud. Dateringen satte dermed et meget præcist årstal på dette udbrud, hvilket rykkede begivenheden omkring 100 år tidligere end den traditionelle arkæologiske placering af udbruddet. Nu kan man måske mene, at 100 år fra eller til er ligegyldigt i den store sammenhæng, men da dateringen rokker ved grundlaget for den arkæologiske placering af det minoiske udbrud i historien, har mange arkæologer haft svært ved at sluge resultatet. På sin vis eksemplificerer sagen derfor et metodologisk sammenstød mellem forskellige fagområder.

I november mødtes nogle af "kombattan-

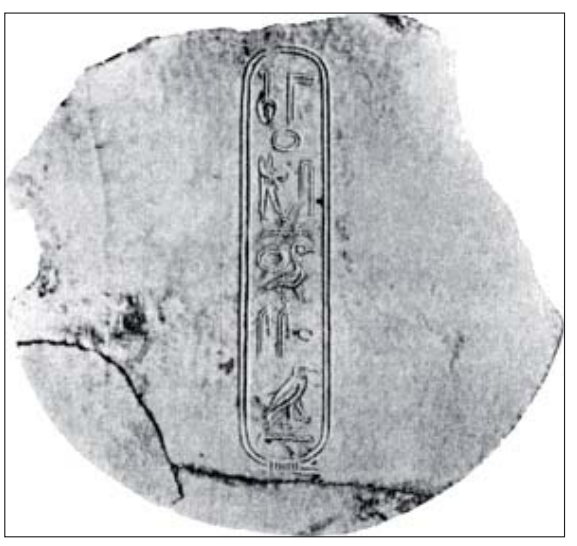

Denne kartouche, som bcerer navnet kong Kyan, der regerede Egypten i den såkaldte Hyksos-periode, er et betydningsfuldt indicium på, at minoerne havde forbindelser med egypterne. Dette fund er lange blevet anset for et vigtigt argument for, at det minoiske vulkanudbrud fandt sted omkring 1.500 år f.Kr.

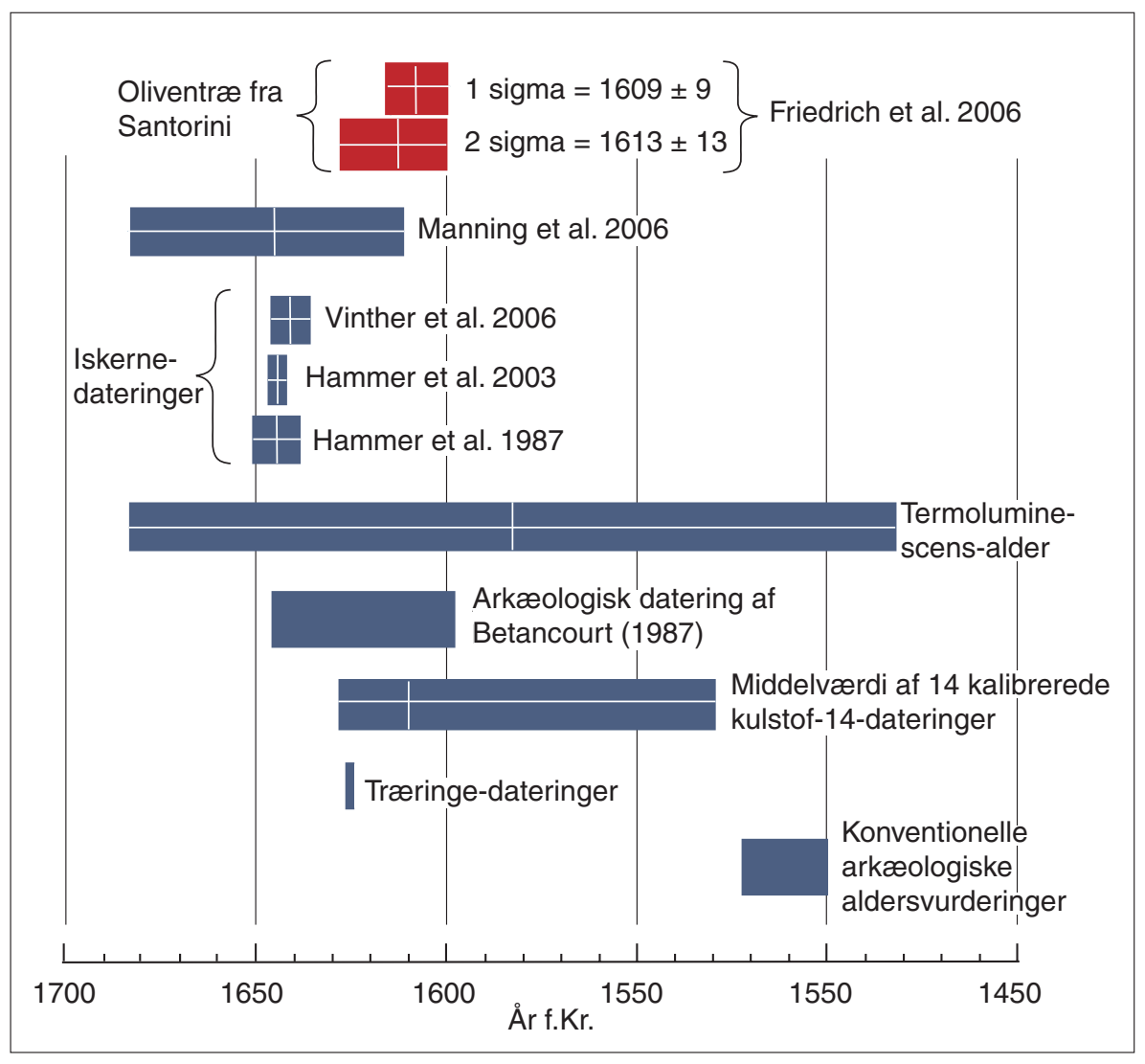

Oversigt over afvigelserne mellem dateringerne af det store minoiske vulkanudbrud. Friedrich et. al.'s er vist med rødt. (Grafik: Friedrich/Aktuel Naturvidenskab)

terne” til en workshop med to af forskerne bag dateringen af olivengrenen, Walter Friedrich og Jan Heinemeier (begge Aarhus Universitet) som medarrangører. De nye dateringsresultater blev drøftet og de principielle uenigheder kortlagt.

\section{Arkæologiske tolkninger}

Udgangspunktet for arkæologernes datering er rekonstruktion af kulturelle forbindelser til den egyptiske kultur og dermed den egyptiske kronologi, der i perioder er usædvanligt veldokumenteret, da man har skriftlige kilder på papyrus, men i andre afsnit er ret mangelfuld og må støtte sig på astronomiske observationer. Ud fra disse data har man med en vis nøjagtighed kunnet afgøre de forskellige egyptiske kongers regeringstid og etablere en kronologi over den egyptiske kultur, der strækker sig fra år 525 f.Kr., da kong Cambyses besejrede Egypterne og derved afsluttede det 26. Dynasti, og nogle tusind år tilbage i tiden.
Den egyptiske kronologi udgør således en reference, som andre kulturers kronologier kan holdes op imod. Den traditionelle arkæologiske datering af den minoiske kulturs historie - og dermed af det minoiske vulkanudbrud - bygger bl.a. på den østrigske arkæolog Manfred Bietaks udgravninger ved det antikke Avaris i Nildeltaet. Bietak er lidt af en guru inden for arkæologien, og hans arbejde med at hægte det minoiske udbrud ind på den egyptiske kronologi bestrides af få arkæologer. Men i Jan Heinemeier og Walter Friedrichs øjne er det nok her, at tingene halter mest set fra et naturvidenskabeligt synspunkt. At matche to kulturers historie ud fra tolkninger af, hvordan forskellige kulturelle påvirkninger kan spores i et materiale - som $\mathrm{fx}$ bestemte stilelementer i keramik - må nødvendigvis indeholde en række subjektive antagelser, der kan vise sig at være uholdbare. Ydermere er der det problem, at den udgravningskronologi, der ligger til grund for tolkningerne, ikke er 
